\title{
Socioeconomic differences in childhood injury: a population based epidemiologic study in Ontario, Canada
}

Taron Faelker, William Pickett, Robert J Brison

\begin{abstract}
Objective-To determine whether risks for childhood injury vary according to socioeconomic gradients.

Design-Population based, retrospective study. The percentage of individuals living below the poverty line (described ecologically using census data) was the primary measure of socioeconomic status.

Setting-Catchment area of a tertiary medical centre that provides emergency services to all area residents. Area residents aged 0-19 years during 1996 were included.
\end{abstract}

Observations-Injuries that occurred during 1996 were identified by an emergency department based surveillance system. The study population was divided into socioeconomic grades based upon percentages of area residents living below the poverty line. Multiple Poisson regression analyses were used to quantify associations and assess the statistical significance of trends.

Results-5894 childhood injuries were identified among 35380 eligible children; 985 children with missing socioeconomic data were excluded. A consistent relation between poverty and injury was evident. Children in the highest grade (indicating higher poverty levels) experienced injury rates that were $1.67(95 \%$ confidence interval 1.48 to 1.89 ) higher than those in the lowest grade (adjusted relative risk for grades 1-V: $1.00,1.10,1.22,1.42, \quad 1.67$; $\left.p_{\text {trend }}<0.001\right)$. These patterns were observed within age/sex strata; for home, recreational, and fall injuries; and for injuries of minor and moderate severities.

Conclusions-Socioeconomic differences in childhood injury parallel mortality and morbidity gradients identified in adult populations. This study confirms that this health gradient is observable in a population of children using emergency department data. Given the population based nature of this study, these findings are likely to be reflected in other settings. The results suggest the need for targeted injury prevention efforts among children from economically disadvantaged populations, although the exact requirements of the optimal prevention approach remain elusive.

(Injury Prevention 2000;6:203-208)

Keywords: injury surveillance; socioeconomic status; poverty
As is the case with many aspects of health and disease, the occurrence of childhood injury has been associated with socioeconomic factors including measures of poverty, ${ }^{1-4}$ education ${ }^{235}$ unemployment, ${ }^{67}$ and social status. ${ }^{89}$ Children of lower socioeconomic status generally have a greater risk of both fatal ${ }^{148-11}$ and non-fatal injury. ${ }^{1-36}$ Although as much as a threefold increase in the risk for non-fatal injury has been observed among impoverished children, ${ }^{1-3}$ others failed to identify any association ${ }^{12-15}$ or attributed the association to other factors, such as race or access to care. ${ }^{16}{ }^{17}$

The study of non-fatal injuries on a population basis is uncommon, and the reporting of these injuries is often dependent on the severity of injury and whether medical care is obtained. The absence of population based data makes it impossible to calculate meaningful rates of injury in most situations. In addition, it is often difficult to construct an accurate measure of socioeconomic status. ${ }^{18} 19$ These factors may account, in part, for any inconsistencies that have been observed. ${ }^{1-3}{ }^{12-17}$ Causal pathways by which socioeconomic factors may affect the occurrence of injury are also not well understood.

The injury experience of children living in poverty is a priority for many researchers. Few studies, however, have examined relationships between socioeconomic status and non-fatal injury in Canada. Due to differences in the manner in which injuries are identified and treated, it is difficult to know whether patterns of injury and health gradients observed in other countries can be generalised.

In this study we had the opportunity to determine whether socioeconomic gradients in health status exist for childhood injuries in the population surrounding Kingston. The study was made possible due to the existence of a population based, emergency department injury surveillance system.

\section{Methods}

A retrospective study was conducted using linked data from the Kingston site of the Canadian Hospitals Injury Reporting and Prevention Program (CHIRPP), ${ }^{20}$ ecologic data on socioeconomic status from the 1996 Canada census of population, ${ }^{21}$ and patient records from two general hospitals. The CHIRPP program was established in 1990, and contains information on emergency room visits for the treatment of injuries presenting to Canada's 10 paediatric hospitals and to six general hospitals. ${ }^{20}$ CHIRPP data from two

Ontario, Canada K7L 2V7

(email:

PickettW@post.queensu.ca) 
Table 1 Distribution of childhood injuries by six indicators of socioeconomic status

\begin{tabular}{|c|c|c|c|c|c|}
\hline Socioeconomic indicator & $\begin{array}{l}\text { Enumeration } \\
\text { areas }\end{array}$ & Children & Injuries & Rate/1000 & Rate ratio $(95 \% \mathrm{CI})$ \\
\hline \multicolumn{6}{|c|}{ Individuals from families living below poverty line (\%) } \\
\hline$<10$ & 79 & 19295 & 2871 & 148.8 & 1.00 \\
\hline $10-19.9$ & 32 & 6420 & 1035 & 161.2 & $1.08(1.00$ to 1.15$)$ \\
\hline $20-29.9$ & 25 & 3475 & 627 & 180.4 & $1.21(1.10$ to 1.31$)$ \\
\hline $30-39.9$ & 21 & 3465 & 686 & 198.0 & $1.33(1.21$ to 1.43$)$ \\
\hline $40+$ & 18 & 2725 & 675 & 247.6 & $1.66(1.52$ to 1.79$)$ \\
\hline \multicolumn{6}{|c|}{ Individuals from families headed by an adult with less than high school education (\%) } \\
\hline$<5$ & 71 & 17120 & 2643 & 154.4 & 1.00 \\
\hline $5-9.9$ & 60 & 11710 & 1969 & 168.1 & $1.08(1.02$ to 1.14$)$ \\
\hline $10-14.9$ & 28 & 4595 & 872 & 189.8 & $1.22(1.13$ to 1.31$)$ \\
\hline $15+$ & 16 & 1955 & 410 & 209.7 & $1.34(1.21$ to 1.49$)$ \\
\hline \multicolumn{6}{|l|}{ Unemployment rate $(\%)$} \\
\hline$<5$ & 29 & 6010 & 883 & 146.9 & 1.00 \\
\hline $5-9.9$ & 8 & 15990 & 2490 & 155.7 & $1.02(0.95$ to 1.11$)$ \\
\hline $10-14.9$ & 41 & 7740 & 1352 & 174.7 & $1.15(1.06$ to 1.25$)$ \\
\hline $15-19.9$ & 23 & 3195 & 656 & 205.3 & $1.35(1.22$ to 1.50$)$ \\
\hline $20+$ & 14 & 2445 & 512 & 209.3 & $1.38(1.24$ to 1.54$)$ \\
\hline \multicolumn{6}{|c|}{ Families headed by a single parent (\%) } \\
\hline$<10$ & 64 & 14130 & 2157 & 152.7 & 1.00 \\
\hline $10-19.9$ & 60 & 11855 & 1943 & 163.9 & $1.06(1.00$ to 1.12$)$ \\
\hline $20-29.9$ & 31 & 6165 & 1063 & 172.4 & $1.11(1.04$ to 1.20$)$ \\
\hline $30+$ & 20 & 3230 & 730 & 226.0 & $1.46(1.34$ to 1.59$)$ \\
\hline \multicolumn{6}{|c|}{ Average dwelling value ( $\$$ Can) } \\
\hline$<120000$ & 43 & 8445 & 1547 & 183.2 & 1.00 \\
\hline $120000-159999$ & 88 & 18675 & 3053 & 163.5 & $0.87(0.82$ to 0.93$)$ \\
\hline $160000-199999$ & 28 & 6030 & 877 & 145.4 & $0.78(0.71$ to 0.84$)$ \\
\hline $200000+$ & 16 & 2230 & 416 & 186.5 & $0.99(0.89$ to 1.11$)$ \\
\hline \multicolumn{6}{|c|}{ Dwellings in need of repair (\%) } \\
\hline$<15$ & 9 & 2005 & 249 & 124.2 & 1.00 \\
\hline $15-29.9$ & 46 & 9840 & 1547 & 157.2 & $1.14(1.00$ to 1.30$)$ \\
\hline $30-44.9$ & 84 & 17310 & 2900 & 167.5 & $1.21(1.07$ to 1.38$)$ \\
\hline $45+$ & 36 & 6225 & 1197 & 192.3 & $1.39(1.22$ to 1.60$)$ \\
\hline
\end{tabular}

$\mathrm{CI}=$ confidence interval.
Information was compiled on all incident cases of injury, inclusive in the International Classification of Diseases, ninth revision (ICD-9) codes E800-E999, ${ }^{23}$ with the exception of: injuries as a result of medical care (E870-E879), therapeutic treatment (E930-E949), or insect bites (E905.1-E905.5, E906.4).

The sampling frame was all children in the population served by the two general hospitals in Kingston, Ontario during the 1996 calendar year, at which time the Kingston Region had a population of 36365 children under 20 years. ${ }^{21}$ Injuries to these children were identified from the CHIRPP system, and the following were obtained for each case: the age, sex and residential postal code of the child, the location and context in which the injury occurred, and the level of treatment received. ICD-9 E codes indicating the mechanism of injury were obtained from hospital records. These records were linked individually to the CHIRPP records using a series of sequential queries based upon: patient chart number, the first three letters of the patient's surname, date of birth, sex, and postal code. Record linkage was achieved in $95 \%$ of cases.

Each postal code was assigned to a Canada census of population enumeration area using the automated geographic coding program, Geocodes/PCCF. ${ }^{24}$ Census enumeration areas range from a maximum of 440 dwellings to a minimum of 125 in some rural areas. ${ }^{25}$ Socioeconomic data were obtained from the veillance Program) are population based for injuries seen at emergency departments. ${ }^{22}$

Table 2 Association between socioeconomic status and childhood injury by sex and five year age group

\begin{tabular}{|c|c|c|c|c|c|}
\hline Subgroup & $\begin{array}{l}\text { Low income } \\
\text { category }{ }^{\star}\end{array}$ & Injuries & Rate/1000 (95\% CI) & $\begin{array}{l}\text { Adjusted rate ratiot } \\
(95 \% \mathrm{CI})\end{array}$ & $\begin{array}{l}\text { Linear trend } \\
\text { test ( } p \text { value) }\end{array}$ \\
\hline Total & $\begin{array}{l}\text { I (rich) } \\
\text { II } \\
\text { III } \\
\text { IV } \\
\text { V (poor) }\end{array}$ & $\begin{array}{r}2871 \\
1035 \\
627 \\
686 \\
675\end{array}$ & $\begin{array}{l}148.8(143.4 \text { to } 154.2) \\
161.2(151.4 \text { to } 171.0) \\
180.4(166.3 \text { to } 194.6) \\
198.0(183.2 \text { to } 212.8) \\
247.7(229.0 \text { to } 266.4)\end{array}$ & $\begin{array}{l}1.00 \\
1.10(1.02 \text { to } 1.19) \\
1.22(1.10 \text { to } 1.35) \\
1.42(1.27 \text { to } 1.60) \\
1.67(1.48 \text { to } 1.89)\end{array}$ & $<0.001$ \\
\hline Females & $\begin{array}{l}\text { I } \\
\text { II } \\
\text { III } \\
\text { IV } \\
\text { V }\end{array}$ & $\begin{array}{r}1110 \\
396 \\
233 \\
274 \\
256\end{array}$ & $\begin{array}{l}119.0(112.0 \text { to } 126.0) \\
124.9(112.6 \text { to } 137.2) \\
136.7(119.1 \text { to } 154.2) \\
156.1(137.6 \text { to } 174.6) \\
184.8(162.2 \text { to } 207.5)\end{array}$ & $\begin{array}{l}1.00 \\
1.04(0.92 \text { to } 1.17) \\
1.04(0.90 \text { to } 1.22) \\
1.23(1.05 \text { to } 1.44) \\
1.46(1.46 \text { to } 1.73)\end{array}$ & $<0.001$ \\
\hline Males & $\begin{array}{l}\text { I } \\
\text { II } \\
\text { III } \\
\text { IV } \\
\text { V }\end{array}$ & $\begin{array}{r}1761 \\
639 \\
394 \\
412 \\
419\end{array}$ & $\begin{array}{l}176.6(168.4 \text { to } 184.9) \\
196.6(181.4 \text { to } 211.9) \\
222.6(200.6 \text { to } 244.6) \\
240.9(217.7 \text { to } 264.2) \\
312.7(282.8 \text { to } 342.6)\end{array}$ & $\begin{array}{l}1.00 \\
1.11(1.01 \text { to } 1.22) \\
1.16(1.03 \text { to } 1.30) \\
1.30(1.16 \text { to } 1.45) \\
1.64(1.46 \text { to } 1.84)\end{array}$ & $<0.001$ \\
\hline $0-4$ years & $\begin{array}{l}\text { I } \\
\text { II } \\
\text { III } \\
\text { IV } \\
\text { V }\end{array}$ & $\begin{array}{l}509 \\
207 \\
123 \\
193 \\
154\end{array}$ & $\begin{array}{l}118.5(108.2 \text { to } 128.8) \\
134.4(116.1 \text { to } 152.7) \\
141.4(116.4 \text { to } 166.4) \\
181.2(155.6 \text { to } 206.8) \\
193.7(163.1 \text { to } 224.3)\end{array}$ & $\begin{array}{l}1.00 \\
1.11(0.93 \text { to } 1.32) \\
1.10(0.87 \text { to } 1.40) \\
1.30(1.02 \text { to } 1.65) \\
1.23(0.93 \text { to } 1.63)\end{array}$ & 0.08 \\
\hline $5-9$ years & $\begin{array}{l}\text { I } \\
\text { II } \\
\text { III } \\
\text { IV } \\
\text { V }\end{array}$ & $\begin{array}{l}579 \\
196 \\
116 \\
120 \\
117\end{array}$ & $\begin{array}{l}113.9(104.6 \text { to } 123.1) \\
124.8(107.4 \text { to } 142.3) \\
138.9(113.6 \text { to } 164.2) \\
142.0(116.6 \text { to } 167.4) \\
182.8(149.7 \text { to } 215.9)\end{array}$ & $\begin{array}{l}1.00 \\
1.07(0.90 \text { to } 1.26) \\
1.08(0.88 \text { to } 1.34) \\
1.09(0.87 \text { to } 1.36) \\
1.32(1.05 \text { to } 1.67)\end{array}$ & 0.04 \\
\hline $10-14$ years & $\begin{array}{l}\text { I } \\
\text { II } \\
\text { III } \\
\text { IV } \\
\text { V }\end{array}$ & $\begin{array}{l}858 \\
289 \\
159 \\
142 \\
154\end{array}$ & $\begin{array}{l}169.2(157.9 \text { to } 180.6) \\
175.2(155.0 \text { to } 195.4) \\
182.8(154.4 \text { to } 211.2) \\
195.9(163.6 \text { to } 228.1) \\
250.4(210.9 \text { to } 290.0)\end{array}$ & $\begin{array}{l}1.00 \\
1.11(0.96 \text { to } 1.29) \\
1.16(0.94 \text { to } 1.42) \\
1.19(0.93 \text { to } 1.52) \\
1.30(0.99 \text { to } 1.70)\end{array}$ & 0.02 \\
\hline $15-19$ years & $\begin{array}{l}\text { I } \\
\text { II } \\
\text { III } \\
\text { IV } \\
\text { V }\end{array}$ & $\begin{array}{l}925 \\
343 \\
223 \\
231 \\
250\end{array}$ & $\begin{array}{l}190.9(178.6 \text { to } 203.2) \\
206.6(184.8 \text { to } 228.5) \\
247.8(215.3 \text { to } 280.3) \\
316.4(275.6 \text { to } 357.2) \\
370.4(324.5 \text { to } 416.3)\end{array}$ & $\begin{array}{l}1.00 \\
1.07(0.93 \text { to } 1.22) \\
1.34(1.13 \text { to } 1.58) \\
1.65(1.36 \text { to } 2.00) \\
2.33(1.92 \text { to } 2.82)\end{array}$ & $<0.001$ \\
\hline
\end{tabular}

$\star$ Low income categories based on \% individuals within enumeration area living in households with incomes below poverty lines Percentages for categories I, II, III, IV, and V were 0-9.9, 10-19.9, 20-29.9, 30-39.9, and 40\%+ respectively.

tAdjusted rate ratios were adjusted for age group, sex, and selected socioeconomic status covariates listed in table 1 .

$\mathrm{CI}=$ confidence interval. 
Table 3 Association between socioeconomic status and childhood injury by type of injury

\begin{tabular}{|c|c|c|c|c|c|}
\hline Injury outcome & $\begin{array}{l}\text { Low income } \\
\text { category }^{\star}\end{array}$ & Injuries & Rate/1000 (95\% CI) & $\begin{array}{l}\text { Adjusted rate ratiot } \\
(95 \% \text { CI) }\end{array}$ & $\begin{array}{l}\text { Linear trend } \\
\text { test ( } p \text { value) }\end{array}$ \\
\hline Home injuries & $\begin{array}{l}\text { I (rich) } \\
\text { II } \\
\text { III } \\
\text { IV } \\
\text { V (poor) }\end{array}$ & $\begin{array}{l}706 \\
262 \\
173 \\
192 \\
213\end{array}$ & $\begin{array}{l}36.6(33.9 \text { to } 39.3) \\
40.8(35.9 \text { to } 45.8) \\
49.8(42.4 \text { to } 57.2) \\
55.4(47.6 \text { to } 63.2) \\
78.2(67.7 \text { to } 88.7)\end{array}$ & $\begin{array}{l}1.00 \\
1.06(0.92 \text { to } 1.23) \\
1.29(1.09 \text { to } 1.52) \\
1.35(1.14 \text { to } 1.60) \\
1.75(1.44 \text { to } 2.13)\end{array}$ & $<0.001$ \\
\hline Sports injuries & $\begin{array}{l}\text { I } \\
\text { II } \\
\text { III } \\
\text { IV } \\
\text { V }\end{array}$ & $\begin{array}{l}828 \\
279 \\
157 \\
140 \\
122\end{array}$ & $\begin{array}{l}42.9(40.0 \text { to } 45.8) \\
43.5(38.4 \text { to } 48.6) \\
45.2(38.1 \text { to } 52.2) \\
40.4(33.7 \text { to } 47.1) \\
44.8(36.8 \text { to } 52.7)\end{array}$ & $\begin{array}{l}1.00 \\
1.02(0.90 \text { to } 1.17) \\
1.06(0.90 \text { to } 1.26) \\
1.08(0.90 \text { to } 1.29) \\
1.16(0.96 \text { to } 1.41)\end{array}$ & 0.10 \\
\hline Recreation or play injuries & $\begin{array}{l}\text { I } \\
\text { II } \\
\text { III } \\
\text { IV } \\
\text { V }\end{array}$ & $\begin{array}{l}895 \\
321 \\
199 \\
225 \\
208\end{array}$ & $\begin{array}{l}46.4(43.4 \text { to } 49.4) \\
50.0(44.5 \text { to } 55.5) \\
57.3(49.3 \text { to } 65.2) \\
64.9(56.4 \text { to } 73.4) \\
76.3(66.0 \text { to } 86.7)\end{array}$ & $\begin{array}{l}1.00 \\
1.06(0.93 \text { to } 1.22) \\
1.08(0.91 \text { to } 1.27) \\
1.17(0.99 \text { to } 1.40) \\
1.37(1.13 \text { to } 1.65)\end{array}$ & 0.004 \\
\hline Injuries from falls & $\begin{array}{l}\text { I } \\
\text { II } \\
\text { III } \\
\text { IV } \\
\text { V }\end{array}$ & $\begin{array}{l}889 \\
307 \\
188 \\
234 \\
205\end{array}$ & $\begin{array}{l}46.1 \text { (43.0 to } 49.1) \\
47.8(42.5 \text { to } 53.2) \\
54.1(46.4 \text { to } 61.8) \\
67.5(58.9 \text { to } 76.2) \\
75.2(64.9 \text { to } 85.5)\end{array}$ & $\begin{array}{l}1.00 \\
1.03(0.90 \text { to } 1.18) \\
1.09(0.92 \text { to } 1.28) \\
1.32(1.13 \text { to } 1.53) \\
1.42(1.21 \text { to } 1.68)\end{array}$ & $<0.001$ \\
\hline Traffic injuries & $\begin{array}{l}\text { I } \\
\text { II } \\
\text { III } \\
\text { IV } \\
\text { V }\end{array}$ & $\begin{array}{r}210 \\
77 \\
31 \\
41 \\
42\end{array}$ & $\begin{array}{c}10.9(9.4 \text { to } 12.4) \\
12.0(9.3 \text { to } 14.7) \\
8.9(5.8 \text { to } 12.1) \\
11.8(8.2 \text { to } 15.4) \\
15.4(10.8 \text { to } 20.1)\end{array}$ & $\begin{array}{l}1.00 \\
1.12(0.86 \text { to } 1.45) \\
0.83(0.57 \text { to } 1.21) \\
1.18(0.84 \text { to } 1.64) \\
1.51(1.08 \text { to } 2.10)\end{array}$ & 0.06 \\
\hline
\end{tabular}

^Low income categories based on \% individuals within enumeration area living in households with incomes below poverty lines. Percentages for categories I, II, III, IV and V were 0-9.9, 10-19.9, 20-29.9, 30-39.9, and 40\%+ respectively.

†Adjusted rate ratios were adjusted for age group, sex, and selected socioeconomic status covariates listed in table 1 . CI $=$ confidence interval.

1996 Canada census. For each enumeration area the following were identified: (1) \% individuals living below the poverty line, ${ }^{26}(2)$ $\%$ individuals with less than a high school education; (3) \% individuals who were unemployed; (4) \% families headed by a single parent; (5) average dwelling value; (6) \% dwellings in need of repair. Enumeration areas were each assigned to levels of socioeconomic status according to the pre-established criteria reflected in table 1 .

The numbers of injuries in the enumeration areas were tabulated by five year age groups and sex, with separate tabulations for the following: (1) total injuries; (2) home injuries (CHIRPP location codes); (3) sports injuries (CHIRPP context codes); (4) recreation or play injuries (CHIRPP context codes); (5) injuries resulting from falls (ICD-9 E800E888); (6) traffic injuries (E810-E829); and (7) injuries of minor, moderate, and extreme severities (CHIRPP disposition codes).

Stratum specific, annual rates of injury (per 1000) were calculated within levels of each of the six indicators of socioeconomic status using denominator data from the census. ${ }^{21}$ Bivariate rate ratios and associated $95 \%$ confidence intervals were calculated for these rates. As would be expected, the socioeconomic indicators were highly correlated (data not shown). Therefore, a single indicator- $\%$ individuals living below the poverty line-was selected for further, etiological analyses. Using this indicator, injury rates and associated $95 \%$ confidence intervals were then calculated for: the total study population, males, females, by five year age group, by injury type, and by level of severity. Associations between socioeconomic status and injury were further investigated using multiple Poisson regression ${ }^{27}$ with simultaneous adjustment for other socioeconomic factors identified via backward selection procedures.
Tests for linear trend ${ }^{28}$ were applied to determine if the calculated rate ratios increased with increasing level of poverty. Sensitivity analyses were then performed to explore whether: (1) gradients in risk could be explained by differential access to emergency medical services by grade ofsocioeconomic status, as indicated by distance to, and multiple use of the emergency departments; (2) exclusion of enumeration areas that were predominantly populated by university/college students changed the observed gradients in risk.

All analyses were conducted in SAS (Cary, NC; version 6.12, 1997) and EGRET (Seattle, WA; SERC; version 0.04, 1994).

\section{Results}

A total of 5894 injuries were identified among the 35380 eligible children during 1996; 985 children with missing socioeconomic data were excluded. Rates of injury are presented in table 1 for various levels of socioeconomic status, as measured by the six indicators. Within each of these indicators there was evidence of statistically significant increases in risk for injury associated with lower levels of socioeconomic status. All provide strong evidence of a linear relationship between increasing economic disadvantage and higher risk for childhood injury.

Table 2 presents injury rates and associated rate ratios for childhood injury for five grades of socioeconomic status (I-V) as indicated by the percentage of individuals living in enumeration areas with household incomes below poverty lines. The observed risk gradient was evident in the rates of injury as well as the adjusted rate ratios. This pattern was observed in both sexes, and each of the age groups. The increases in risk and the observed gradient were especially strong in the 15-19 year old age group. Although still apparent, the gradient in 
Table 4 Association between socioeconomic status and childhood injury: by severity of injury

\begin{tabular}{|c|c|c|c|c|c|}
\hline Severity & $\begin{array}{l}\text { Low income } \\
\text { category }{ }^{\star}\end{array}$ & Injuries & Rate/1000 (95\% CI) & $\begin{array}{l}\text { Adjusted rate ratio } \\
(95 \% \text { CI })\end{array}$ & $\begin{array}{l}\text { Linear trend } \\
\text { test ( } p \text { value) }\end{array}$ \\
\hline Minorf & $\begin{array}{l}\text { I (rich) } \\
\text { II } \\
\text { III } \\
\text { IV } \\
\text { V (poor) }\end{array}$ & $\begin{array}{r}1789 \\
648 \\
417 \\
434 \\
448\end{array}$ & $\begin{array}{l}92.7(88.4 \text { to } 97.0) \\
100.9(93.2 \text { to } 108.7) \\
120.0(108.5 \text { to } 131.5) \\
125.2(113.5 \text { to } 137.0) \\
164.4(149.2 \text { to } 179.6)\end{array}$ & $\begin{array}{l}1.00 \\
1.06(0.96 \text { to } 1.16) \\
1.12(1.00 \text { to } 1.26) \\
1.18(1.04 \text { to } 1.33) \\
1.50(1.32 \text { to } 1.71)\end{array}$ & $<0.001$ \\
\hline Moderate $\ddagger$ & $\begin{array}{l}\text { I } \\
\text { II } \\
\text { III } \\
\text { IV } \\
\text { V }\end{array}$ & $\begin{array}{r}1011 \\
355 \\
201 \\
229 \\
208\end{array}$ & $\begin{array}{l}52.4(49.2 \text { to } 55.6) \\
55.3(49.5 \text { to } 61.0) \\
57.8(49.8 \text { to } 65.8) \\
66.1(57.5 \text { to } 74.6) \\
76.3(66.0 \text { to } 86.7)\end{array}$ & $\begin{array}{l}1.00 \\
1.05(0.92 \text { to } 1.20) \\
1.20(1.00 \text { to } 1.42) \\
1.51(1.25 \text { to } 1.83) \\
1.73(1.40 \text { to } 2.13)\end{array}$ & $<0.001$ \\
\hline Extreme $\$$ & $\begin{array}{l}\text { I } \\
\text { II } \\
\text { III } \\
\text { IV } \\
\text { V }\end{array}$ & $\begin{array}{r}53 \\
22 \\
4 \\
15 \\
13\end{array}$ & $\begin{array}{l}2.8(2.0 \text { to } 3.5) \\
3.4(2.0 \text { to } 4.9) \\
1.2(0.0 \text { to } 2.4) \\
4.3(2.1 \text { to } 6.5) \\
4.8(2.2 \text { to } 7.4)\end{array}$ & $\begin{array}{l}1.00 \\
1.09(0.66 \text { to } 1.81) \\
0.37(0.13 \text { to } 1.02) \\
1.45(0.77 \text { to } 2.71) \\
1.53(0.76 \text { to } 3.06)\end{array}$ & 0.35 \\
\hline
\end{tabular}

^Low income categories based on \% individuals within enumeration area living in households with incomes below poverty lines. Percentages for categories I, II, III, IV, and V were 0-9.9, 10-19.9, 20-29.9, 30-39.9, and 40\%+ respectively.

†Treated with advice only or treated and follow up not required.

$\ddagger$ Treated and follow up required or required a short stay in emergency department.

SAdmitted to hospital or transferred to another hospital.

TAdjusted rate ratios were adjusted for age group, sex, and selected socioeconomic status covariates listed in table 1 .

$\mathrm{CI}=$ confidence interval.

this age group was weakened after exclusion of the university/college enumeration areas (data not shown).

Table 3 summarises a similar analysis for different types of injury outcomes. Gradients of risk by socioeconomic status were evident for home, recreation/play, and fall injuries, but there was little suggestion of a gradient for sports injuries. Table 4 shows that that the observed gradients were also seen in injuries of varying severities, although the gradient for extreme injuries was not statistically significant. Finally, the risks observed did not change substantially when the enumeration areas from outside of the urban core were excluded from the analysis, or when children who were injured more than once were removed from the analysis (data not shown).

\section{Discussion}

The major finding of this population based, retrospective study was that socioeconomic gradients exist for childhood injuries. The study is regarded as "ecological" because socioeconomic status was defined for each case based upon ecological observations made at the census tract level. Children living in impoverished areas experienced higher rates of non-fatal injury relative to more affluent neighbourhoods. Further, this gradient was observed consistently within subgroups of the population, and for injuries of different types and severity.

These findings are consistent with many past studies of childhood injury. When children from the most disadvantaged backgrounds/ settings are compared with affluent children, major disparities in risk for childhood injury fatalities have been observed; for example: 1.31.7 to 1 (United States), ${ }^{11} 2.6$ to 1 (Maine, USA), ${ }^{4}$ and 2 to 1 with higher ratios for fires, falls, and drownings (Great Britain). ${ }^{8}$ Disparities by income quintile have also been reported for injuries presenting to emergency departments ( 3 to 1; Australia), ${ }^{3}$ hospitalizations (1.6-4.5 to 1 , dependent upon cause; Northern Manhattan, USA), ${ }^{2}$ and traffic injuries that lead to death, hospitalization, or a police inquiry (4 to 1 ; Montreal, Canada). ${ }^{1}$ The overall gradient in risk observed in the present study ( 1.67 to 1 , for incomes quintiles $\mathrm{V} v 1$ ) is relatively modest compared with the above findings, but substantial compared with others who examined the full spectrum of medically treated injuries reported by children in Australia, for example Langley et $a l,{ }^{12}$ and Great Britain, for example Williams et al. ${ }^{15} 1 \mathrm{t}$ appears, therefore, that that the strength of the childhood injury gradient observed by socioeconomic levels may be modified by specific study conditions, including the type and severity of injury under study, and conditions specific to the country and population being examined. The latter may include the nature of health care systems, and differential access to medical care by socioeconomic class. The observed gradient in Kingston is unlikely to be confounded by these factors, as the major options for medical treatment of childhood injuries are the two hospital based emergency departments, and all Canadian children are enrolled in a single, universally accessible health system. Further, family physicians in our area refer virtually all injuries to emergency for care, and the two walk-in clinics that are open in off-hours are not equipped with $x$ ray facilities, and use the same referral practices (R J Brison, Director CHIRPP, personal communication, 1999).

The Black report from the United Kingdom is the sentinel study of associations between social class and health outcomes. ${ }^{8}{ }^{29}$ Large and persistent differences in mortality by occupational class were observed for many causes of death, including those associated with unintentional injury. A particularly steep class gradient was observed for childhood injuries. ${ }^{8}$ Explanations for these health gradients include material deprivation ${ }^{30}$ and societal barriers that would make it difficult for those in the lower classes to protect their children from injury. ${ }^{29}$ Individuals living in poverty also experience high levels of stress and associated illnesses, ${ }^{31}$ and have fewer resources to allocate towards supervised child care ${ }^{32}$ or safety measures in the 
home. ${ }^{33}$ Impoverished neighbourhoods may also have fewer safe play areas such as parks and fenced-in yards, or they may be closer to busy streets and industrial sites. Although these conditions contribute to differential injury risks in other populations, we were unable to verify their causal connections because of limitations in our data. This level of detail is not collected routinely as part of the CHIRPP or hospital data protocols.

The observed socioeconomic gradient was not observed for every injury outcome, and this is consistent with the findings of others. ${ }^{34}$ The failure to observe a strong gradient for sports injury may be attributable to the different opportunities, and hence exposure, to sports activities among children in different socioeconomic grades. Children from impoverished areas may be less likely to participate in sports because of the high costs of registration and equipment. For traffic injuries and for injuries of extreme severity, although the results were suggestive, our failure to identify a statistically significant gradient was likely due to the limited numbers of cases in these subgroups. Past studies have demonstrated strong socioeconomic gradients for pedestrian and bicycle injuries $^{35} 36$ and fatalities. ${ }^{59}$

As stated previously, it is unlikely that the observed gradient can be attributed to differential access or use of emergency medical services by grade of socioeconomic status. This might also occur if people from different grades were required to travel different distances to use the emergency system. However, when the analysis was stratified by distance to the hospitals, a similar gradient was observed within each distance stratum. Further, we postulated that people from impoverished areas might use the emergency department as their sole source of emergency care, whereas others would sometimes use other forms of care in emergency situations. ${ }^{37}$ If true, this difference in access could explain the gradient. We believe this explanation to be unlikely. When repeat visits by the same children were removed from the analysis, the gradients by socioeconomic status remained. Further, a similar risk gradient was observed for severe injuries (table 4), all of which would be expected to present to emergency for treatment, irrespective of socioeconomic status. These analyses suggest that the gradients in childhood injury cannot be dismissed as reporting artefacts.

The major strengths of this investigation are as follows. The study examined a large population of children in a well defined geographic region. The population based nature of the injury surveillance system is unique. We are unaware of any other emergency based surveillance systems that have this feature in Canada. Although the CHIRPP system is limited because $\mathrm{E}$ codes are not recorded, this was overcome by linking CHIRPP records with patient records held by the two participating hospitals. Finally, the study examined a variety of indicators of socioeconomic status, including measures of household income, education, unemployment, the absence of two parents, and dwelling values and condition. While these each measured slightly different aspects of the same construct, the percentage of households with incomes below poverty lines appeared to provide the best indication of childhood poverty. The observed gradient in risk was strongest for this indicator, and remained unchanged after simultaneous adjustment for each of the other socioeconomic measures. This provides direction for the selection of socioeconomic indicators in future investigations of this type.

The study also had some important limitations. Because socioeconomic data could not be obtained at an individual level, the exposure assessment was ecological in nature. Inferences about the effects of poverty on the occurrence of childhood injury must be made with caution due to the ecologic fallacy. ${ }^{38}$ Our analysis was also limited by the amount of available information on potentially important covariates (for example parental and child behaviour attributes) that could have affected the relationship between socioeconomic status and injury risks. Finally, the injuries under study were attributed to socioeconomic characteristics of the areas in which children live, although they could have been caused by hazards in other locations. It is probable that even stronger gradients in risk were masked due to this misclassification of exposure.

\section{Implications and conclusion}

The results of this study suggest that socioeconomic gradients in health status exist for childhood injuries treated in emergency departments. These gradients parallel mortality and morbidity patterns identified in adult and other child populations. We believe that this study is a unique contribution to the Canadian injury literature. It is also one of the first international studies to describe the childhood injury gradient both overall, and for a variety of injury types, using emergency department data assembled comprehensively for an entire population. Given the population based nature of this study, these findings are likely to be found in other settings.

The results suggest the need for local and national authorities to target injury prevention efforts among children from economically disadvantaged populations. Formal surveillance of the hazards to which these children are exposed may also be warranted. However, few interventions to reduce childhood injury in these populations have been rigorously evaluated, and the optimal approach to prevention remains elusive. Home visitation programs have been advocated as one possible solution, for example postnatal home visits to socially disadvantaged mothers have been associated with reduced rates of early childhood injury, ${ }^{39}$ and (by extrapolation) this strategy may be efficacious in other situations. In general, however, purely educational measures (targeted or otherwise) have not been shown to reduce childhood injuries in the short term. ${ }^{40}$ The most promising interventions for socially disadvantaged children are legislative and regulatory controls, ${ }^{40}$ or a combination of legislation, 
environmental modification, and educational efforts implemented at the community level, combined with the sustained use of surveillance. ${ }^{41}$ Our findings suggest that these interventions should be directed specifically towards the amelioration of home, recreational and fall injury hazards, as these are particularly important injury patterns among socially disadvantaged children.

Financial support was provided by the Child Injury Division of Health Canada and the KFLA/Queen's Teaching Health Unit.
The authors thank Kathy Bowes from the Kingston and Region The authors thank Kathy Bowes from the Kingston and Region Injury Surveillance Program (data collection), and Russel Wilkins from Health Canada (provision of the Geocodes/PCCF program). Dr Pickett is a Career Scientist
Ministry of Health and Long-term Care.

1 Dougherty G, Pless IB, Wilkins R. Social class and the occurrence of traffic injuries and deaths in urban children. Can $\mathcal{F}$ Public Health 1990;81:204-9.

2 Durkin MS, Davidson LL, Kuhn L, et al. Low-income neighborhoods and the risk of severe pediatric injury: a small-area analysis in northern Manhattan. Am $\mathcal{F}$ Public Health 1994;84:587-92.

3 Jolly DL, Moller JN, Volkmer RE. The socio-economic context of child injury in Australia. 7 Paediatr Child Health 1993;29:438-44.

4 Nersesian WS, Petit MR, Shaper R, et al. Childhood death and poverty: a study of all childhood deaths in Maine, 1976 to 1980 . Pediatrics $1985 ; 75: 41-50$.

5 Scholer SJ, Mitchel EF Jr, Ray WA. Predictors of injury mortality in early childhood. Pediatrics $1997 ; 100: 342-7$.

6 Roberts I, Marshall R, Norton R, et al. An area analysis of child injury morbidity in Auckland. $\mathcal{F}$ Paediatr Child Health child injury morbid

7 Harris MJ, Kotch JB. Unintentional infant injuries: Harris MJ, Kotch JB. Unintentional infant injuries: sociodemographic

8 Black D, Morris J, Smith C, et al. Inequalities in health. (Black report.) Markham: Penguin Books, 1982.

9 Roberts I. Cause specific social class mortality differentials for child injury and poisoning in England and Wales. $\mathcal{F} E \mathrm{pi}$ demiol Community Health 1997;51:334-5.

10 Wise PH, Kotelchuck M, Wilson ML, et al. Racial and socioeconomic disparities in childhood mortality in Boston. N Engl f Med 1985;313:360-6.

11 Mare RD. Socioeconomic effects on child mortality in the United States. Am $\mathcal{F}$ Public Health 1982;72:539-47.

12 Langley J, Silva P, Williams S. Socio-economic status and childhood injuries. Aust Paediatr F 1983;19:237-40.

13 Anderson R, Dearwater SR, Olsen T, et al. The role of socioeconomic status and injury morbidity risk in adolescecioeconomic status and injury modiatr Adolesc Med 1994;148:245-9.

14 Addor V, Santos-Eggimann B. Population-based incidence of injuries among preschoolers. Eur $\mathcal{F}$ Pediatr 1996;155 $130-5$.

15 Williams JM, Currie CE, Wright P, et al. Socioeconomic status and adolescent injuries. Soc Sci Med 1997;44:188191.

16 Overpeck MD, Jones DH, Trumble AC, et al. Socioeconomic and racial/ethnic factors affecting non-fatal medically attended injury rates in US children. Inj Prev 1997;3 $272-6$.

17 Scheidt PC, Harel Y, Trumble AC, et al. The epidemiology of nonfatal injuries among US children and youth. $A m f$ Public Health 1995;85:932-8.
18 Krieger N, Williams DR, Moss NE. Measuring social class in US public health research: concepts, methodologies, and guidelines. Annu Rev Public Health 1997;18:341-78.

19 Liberatos P, Link BG, Kelsey JL. The measurement of social class in epidemiology. Epidemiol Rev 1988;10:87-121.

20 Mackenzie SG, Pless IB. CHIRPP: Canada's principal injury surveillance program. Inj Prev 1999;5:208-13.

21 Statistics Canada. 1996 Census of population. Ottawa: Statistics Canada, 1998.

22 Bienefeld M, Pickett W, Carr PA. A descriptive study of childhood injuries in Kingston, Ontario, using data from a computerized injury surveillance system. Chronic Diseases in Canada 1996;17:21-7.

23 International Classification of Diseases, 9th revision - clinical modification. 3rd Ed. US Department of Health and Human Services, 1989.

24 Health Statistics Division SC. Geocodes/PCCF version 3 user's guide. Automated geographic coding based on the Statistics Canada postal code conversion files. Ottawa: Statistics Canada, 1998.

25 Statistics Canada. 1996 Census dictionary (92-351-XPE). 1996 Census of Canada. Ottawa: Industry Canada, 1997.

26 Library of Parliament. Poverty in Canada. Ottawa: Minister of Supply and Services Canada, 1996.

27 Kleinbaum DG, Kupper LL, Muller KE. Applied regression analysis and other multivariable methods. 2nd Ed. Boston: PWS-Kent Publishing Company, 1988.

28 Rosner B. Fundamentals of biostatistics. 4th Ed. Toronto: Woodsworth Publishing Company, 1995.

29 Hertzman C, Frank J, Evans RG. Heterogeneities in health status and the determinants of population health. In: Evans RG, Barer ML, Marmor TR, eds. Why are some people healthy and others not? New York: Aldine De Gruyter, 1994: 67-92.

30 Townsend P, Phillimore P, Beattie A. Health and deprivation. London: Croom Helm, 1988.

31 Canadian Public Health Association. Health impacts of social and economic conditions: implication for public policy. Ottawa: Canadian Public Health Association, 1997.

32 Gustafsson LH. Childhood accidents. Scand f Soc Med 1977;5:5-13.

33 Paul CL, Redman S, Evans D. The cost and availability of devices for preventing childhood injuries. 7 Paediatr Child Health 1992;28:22-6.

34 Mummery WK, Spence JC, Vincenten JA, et al. A descriptive epidemiology of sport and recreation injuries in a population-based sample: results from the Alberta sport and recreation injury survey. Can F Public Health 1998;89: 53-6.

35 Joly MF, Foggin PM, Pless IB. Geographical and socioecological variations of traffic accidents among children. Soc Sci Med 1991;33:765-9.

36 Braddock M, Lapidus G, Gregorio D, et al. Population, income, and ecological correlates of child pedestrian injury. Pediatrics 1991;88:1242-7.

37 Leslie DR. Health and poverty. New York: Haworth Press, 1997

38 Morgenstern H. Ecologic studies in epidemiology: concepts, principles, and methods. Anпu Rev Public Health 1995; 16:61-81.

39 Hodnett ED, Roberts I. Home-based social support for socially disadvantaged mothers. (Cochrane review.) Cochrane Library, Issue 1, 2000. Oxford: Update Software.

40 Munro J, Coleman P, Nicholl J, et al. Can we prevent accidental injury to adolescents? A systematic review of the evidence. Inj Prev 1995;1:249-55.

41 Dowswell T, Towner EM, Simpson G, et al. Preventing childhood unintentional injuries - what works? A literature review. Inj Prev 1996;2:140-9. 